\begin{tabular}{|c|c|}
\hline Title & Characterization of H3N6 avian influenza virus isolated from a wild white pelican in Zambia \\
\hline Author(s) & $\begin{array}{l}\text { Simulundu, Edgar; Mweene, A aron S.; T omabechi, Dai suke; Hang'ombe, Bernard M.; Ishii, A kihiro; Suzuki, Y uka; } \\
\text { Nakamura, Ichiro; Sawa, Hirofumi; Sugimoto, Chihiro; Ito, Kimihito; Kida, Hiroshi; Saiwana, Lewis; T akada, A yato }\end{array}$ \\
\hline Citation & $\begin{array}{l}\text { A rchives of V irology, 154(9), 1517-1522 } \\
\text { https://doi.org/10.1007/s00705-009-0467-9 }\end{array}$ \\
\hline Issue Date & 2009-09 \\
\hline Doc URL & http:/hdl.handle.net/2115/43811 \\
\hline Rights & The original publication is available at www.springerlink.com \\
\hline Type & article (author version) \\
\hline File Information & A V 154-9_1517-1522.pdf \\
\hline
\end{tabular}

Instructions for use 
1

2

3

\section{Characterization of H3N6 avian influenza virus isolated from a wild white pelican in}

2 Zambia.

3

4 Edgar Simulundu ${ }^{\mathrm{a}}$, Aaron S. Mweene ${ }^{\mathrm{b}}$, Daisuke Tomabechi ${ }^{\mathrm{a}}$, Bernard M. Hang'ombe ${ }^{\mathrm{c}}$, 5 Akihiro Ishii $^{\text {a, d }}$, Yuka Suzuki ${ }^{\text {a, d }}$, Ichiro Nakamura ${ }^{\text {a, b }}$, Hirofumi Sawa ${ }^{\text {a, b }}$,

6 Chihiro Sugimoto $^{\text {a, b }}$, Kimihito Ito ${ }^{\text {a }}$, Hiroshi Kida ${ }^{\text {a, e, f }}$, Lewis Saiwana ${ }^{\mathrm{g}}$, and Ayato Takada ${ }^{\text {a, b, * }}$ 7

$8{ }^{\text {a }}$ Hokkaido University Research Center for Zoonosis Control, Kita-20, Nishi-10, Kita-ku, 9 Sapporo 001-0020, Japan.

$10{ }^{\mathrm{b}}$ Department of Disease Control, School of Veterinary Medicine, The University of Zambia, P. 11 O. Box 32379, Lusaka, Zambia.

$12{ }^{\mathrm{c}}$ Department of Paraclinical studies, School of Veterinary Medicine, The University of Zambia, 13 P. O. Box 32379, Lusaka, Zambia.

$14{ }^{\mathrm{d}}$ Hokudai Center for Zoonosis Control in Zambia, School of Veterinary Medicine, The 15 University of Zambia, P. O. Box 32379, Lusaka, Zambia.

$16{ }^{\mathrm{e}}$ Department of Disease Control, Graduate School of Veterinary Medicine, Hokkaido University, 17 Sapporo 060-0818, Japan.

$18{ }^{\mathrm{f}}$ OIE Reference Laboratory for Highly Pathogenic Avian Influenza, Japan.

$19{ }^{\mathrm{g}}$ Zambia Wildlife Authority, Private Bag 1, Kafue Road, Chilanga, Zambia

$20 *$ Corresponding author: Dr. Ayato Takada

21 Mailing address: Department of Global Epidemiology, Hokkaido University Research Center

22 for Zoonosis Control, Sapporo 001-0020, Japan

23 Telephone: $+81-11-706-9502$

24 Fax: +81-11-706-7310

25 Email: atakada@czc.hokudai.ac.jp 
2

3

4

\section{Abstract}

28 We characterized an influenza virus isolated from the Great White Pelican in Zambia.

29 Phylogenetic analyses showed that all gene segments belonged to the Eurasian lineage and that

30 they appear to have evolved in distinct geographical regions in Europe, Asia, and Africa,

31 suggesting reassortment of virus genes maintained in wild aquatic birds whose flyways overlap

32 across these continents. It was notable that this virus might possess some genes of the same

33 origin as those of highly pathogenic $\mathrm{H} 7$ and $\mathrm{H} 5$ viruses isolated in Eurasia. The present study

34 underscores the need for continued monitoring of avian influenza viruses in Eurasia and Africa. 
35 Aquatic birds of the orders Anseriformes (ducks, geese, and swans) and Charadriiformes (gulls, 36 terns, and shorebirds) are thought to constitute the major natural reservoir for avian influenza

37 (AI) A virus [20,24]. All known influenza A virus subtypes with respect to two surface

38 glycoproteins, hemagglutinin (HA) (H1-H16) and neuraminidase (NA) (N1- N9) and most

39 HA/NA combinations have been identified in wild birds and poultry $[11,24]$. Influenza A viruses

40 of avian origin have been implicated in outbreaks of influenza in other hosts [13,20,24],

41 indicating that a vast influenza virus gene pool for future epidemics in other animal species

42 including human pandemics exists in avian sources. 56 avian host in Zambia.

In August 2006, fifty one fresh fecal samples were collected from apparently healthy pelicans in 
59 Lochinvar national park $\left(15^{\circ} 40^{\prime} \mathrm{S} ; 27^{\circ} 15^{\prime} \mathrm{E}\right)$, in Southern province of Zambia. Virus isolation

60 was attempted in 10- to 11-day- old embryonated chicken's eggs. One influenza virus isolate was

61 obtained and designated A/pelican/Zambia/01/06 (H3N6) (Zb06) following subtyping by

62 standard hemagglutination inhibition (HI) and neuraminidase inhibition (NI) tests using specific

63 antisera to the reference strains of influenza viruses. We then prepared chicken antisera against

64 Zb06. Briefly, purified virus was inactivated with $0.1 \%$ formalin at $4{ }^{\circ} \mathrm{C}$ for one week. Three-

65 month-old specific-pathogen-free chickens were immunized intramuscularly and subcutaneously

66 with $100 \mu 1$ of $300 \mu \mathrm{g}$ inactivated virus with Complete Freund's Adjuvant (DIFCO). The chickens

67 were re-immunized two weeks later similarly but with Incomplete Freund's Adjuvant. The

68 chickens were given a third intravenous booster injection without adjuvant three weeks after the

69 second immunization. One week after the final immunization, the chickens were sacrificed to

70 obtain serum. We used A/Puerto Rico/8/34 (H1N1) (PR8), A/duck/Hong Kong/836/80 (H3N1)

71 (DHK836), A/Aichi/2/68 (H3N2) (Aichi), A/Memphis/1/96 (H3N2) (Mem96),

72 A/Czeckoslovakia/56 (H4N6) (Czec56), A/duck/England/1/56 (H11N6) (Eng56), A/gull

73 /Maryland/704/77 (H13N6) (MD77), and Zb06 for antigenic characterization by $\mathrm{HI}$ and NI

74 assays. Chicken antiserum were raised against these viruses except DHK836. Chicken

75 erythrocytes (0.5\%) and Fetuin, Fetal Bovine Serum (CALBIOCHEM), were used in the HI and

76 NI assays, respectively.

77

78 In antigenic analyses, chicken antiserum raised against $\mathrm{Zb06}$ showed high $\mathrm{HI}$ and NI titers

79 roughly equally to all the $\mathrm{H} 3$ and $\mathrm{N} 6$ influenza viruses tested, including the relatively recent

80 human strain, Mem96 (Table 1), indicating that chicken antiserum raised against Zb06 has high

81 cross reactivity. The reason for the high cross reactivity is unclear, but one possibility is that

82 antibodies raised against $\mathrm{Zb} 06$ predominantly recognize the conserved epitopes of the surface 
83 glycoproteins of the viruses tested. Chicken antiserum raised against $\mathrm{Zb06}$ could therefore be

84 useful in diagnosis of $\mathrm{H} 3$ and N6 influenza viruses. On the other hand, Zb06 did not react with

85 chicken antisera raised against Mem96 but reacted with antiserum against Aichi (<40 and $320 \mathrm{HI}$

86 titers, respectively), confirming antigenic drift which has been observed since this virus was first

87 introduced into the human population [2].

89 For genetic analyses, viral RNA was extracted and amplified by RT-PCR as described previously 90 [12]. PCR products were purified from agarose gels and then sequenced directly using BigDye 91 terminator cycle sequencing ready reaction kit and analyzed on a 3130 Genetic analyzer

92 (Applied Biosystems). The nucleotide sequences obtained in this study will appear in the $93 \mathrm{DDBJ} / \mathrm{EMBL} / \mathrm{GenBank}$ nucleotide sequence databases under accession numbers $\underline{\mathbf{A B 4 7 0 2 9 3}}$ to

94 AB470300. Phylogenetic trees were constructed using the neighbor-joining bootstrap method 95 (1,000 replicates) in MEGA4.

97 The entire genome of Zb06 was completely sequenced and analyzed with the basic local 98 alignment search tool (BLAST) available from Genbank (Table 2). We found that the HA, PB2, 99 and NS genes were highly similar (97-99\%) to duck/South Africa/1108/04 (H3N8) (SAH3). The 100 NP and PB1 genes showed 97\% nucleotide similarity with H7N1 and H7N3 influenza viruses 101 isolated from Italian poultry, respectively. The closest relative of $\mathrm{Zb06} \mathrm{M}$ gene was 102 duck/Mongolia/54/2001 (H5N2) (98\% nucleotide similarity). The NA segment was close to 103 mallard/Germany/Wv1806-09k/03 (H4N6) with 96\% nucleotide identity. The PA gene showed 104 close sequence identity (98\%) to H5N3 virus, teal/Italy/3812/05.

106 The HA, NA, NP, and PA gene phylograms are shown in Fig. 1. Phylogenetic analysis of the HA 
gene of Zb06 showed the separation of the viruses into the Eurasian, American, and humanswine lineages (Fig. 1a). Sublineages 1-3 are distinguishable within the Eurasian lineage. The HA gene of $\mathrm{Zb06}$ was closely related to that of $\mathrm{SAH} 3$, and belonged to the first sublineage, comprising viruses isolated mainly from the Far East and Europe. The much older virus, duck/Ukraine/1/63 (H3N8) and a swine isolate from Mongolia constituted the second Eurasian sublineage. The third sublineage is composed of $\mathrm{H} 3 \mathrm{~N} 2$ viruses isolated from fecal specimens collected from live poultry markets in Korea [21]. The NA gene tree of Zb06 revealed the assortment of viruses into the Eurasian, Eurasian-American, Oceania, and American lineages (Fig. 1b). Two sublineages were apparent within the Eurasian lineage, "contemporary" and 1970s and 1980s viruses (designated 1 and 2, respectively). The NA gene of Zb06 fell in the “contemporary" sublineage and was closely related to H4N6 viruses isolated from Germany and Norway. Aside from Zb06 and the two H4N6 European strains, all viruses of the "contemporary" sublineage were of Asian origin. Except for three viruses, Eng56, Czec56, and duck/Siberia/272/ 98 (H13N6) the Eurasian-American lineage was composed exclusively of shorebird and gull viruses isolated in America and Eurasia.

Phylograms of the internal protein genes (NP and PA) (Fig. 1c, and d) of Zb06 showed the clustering of strains of the Eurasian lineage into sublineages as previously described [9]. In the NP phylogeny, four groups or sublineages are recognized. The first group consists of recent isolates from Europe, Asia and South Africa, including HP H5N1 viruses isolated from ducks and chickens in China, and from whooper swans in Japan. The NP gene of Zb06 belonged to the second group, consisting of “early” European strains represented by Dk/Potsdam/2216-4/84 (H5N6) and some recent isolates, including H7N1 Italian poultry viruses [1]. The third sublineage was composed of a single isolate, Dk/Hokkaido/120/01 (H6N2). The fourth group of 
131 the Eurasian lineage comprises 3 strains isolated from 1956 to 1961. The PA phylogram was

132 topologically similar to that of the NP gene tree. In contrast to the NP gene that clustered with $133 \mathrm{H} 7 \mathrm{~N} 1$ Italian poultry viruses, the PA gene of Zb06 was closely related to that of 134 teal/Italy/3812/05 (H5N3) and grouped together with those of the Asian HP H5N1 viruses, 135 suggesting a common source of the PA gene of these viruses.

137 The close relation of the HA, and internal (NS and PB2) protein genes (Supplementary Fig. S1) 138 of Zb06 to those of wild bird isolates from South Africa suggests that some reassortment may 139 have occurred within sub-Saharan Africa due to the interaction of wild birds through the intra140 African flyways. Ring recoveries of water birds in Southern Africa have shown that some 141 waterbirds are migratory within southern Africa, while others show dispersal as far as central 142 Africa [23]. Phylogenies of the NP, and other internal (NS, PB1, and M) protein genes 143 (Supplementary Fig. S1) of Zb06 showed that they were closely related to $\mathrm{H} 7$ influenza viruses 144 isolated from Italian poultry in 1999, suggesting that viruses of the same origin as Zb06 may 145 have contributed some internal protein genes to viruses that caused epidemics of AI of H7 146 viruses that have been observed in Europe since 1997 [1,3,4,8]. Phylogenetic analyses of AI 147 viruses isolated from wild ducks and domestic poultry in Italy revealed that the precursor $\mathrm{H} 7$ 148 virus for AI in domestic poultry was directly introduced from migratory birds [4]. The close 149 similarity of these genes of $\mathrm{Zb06}$ to those of the viruses isolated in Italy leads us to speculate that 150 these viruses may have infected their avian hosts on the Black Sea/Mediterranean flyway which, 151 together with the East Africa/West Asia flyway pass through Zambia. We acknowledge the need 152 for caution in interpreting our data because only very limited sequence data from African wild 153 birds are available in Genbank. 
155 Until now, there was no report of influenza virus isolation from the Great White Pelican

156 (Pelecanus onocrotalus). Influenza virus (H6N1) isolation from Great Cormorant, a member of

157 the order Pelecaniformes, has been reported [22]. Other studies did not yield positive results of 158 influenza virus isolation from this order $[17,19,20]$. The Great White pelican is endemic in 159 Southern Africa. Limited breeding sites exist in the region including two in South Africa, and 160 one in Namibia [6,7]. Large colonies of white pelicans congregate in Lochinvar national park 161 sharing same habitat with other bird species in which AI viruses have been frequently isolated 162 worldwide. The role of "minor" bird reservoirs in influenza virus ecology is unclear. It remains 163 to be determined in which of these species influenza viruses are endemic and in which the virus 164 is a temporary pathogen $[19,20]$.

166 Available evidence suggests that the rapid spread of HP H5N1 virus from Qinghai lake, China, 167 to Europe and Africa may have involved migratory birds and possibly the poultry trade [14]. The 168 close relation of the PA gene of Zb06 to those of the Asian HP H5N1 viruses implies that wild 169 birds could carry and spread, at least in part, genes of the same origin as those of HP AI viruses 170 over large geographical regions. The overlap of multiple migratory flyways within Eurasia and 171 Africa permits virus-infected birds of different bird populations to transmit pathogens to new 172 hosts that may carry them to new areas [20].

174 While AI A viruses have evolved into two genetically distinct lineages, Eurasian and American, 175 possibly due to long-term confinement of birds to distinct flyways [20,24], transcontinental 176 introduction of AI virus genes has been described between the two lineages [16,18]. For 177 instance, PB2 and PA genes of the American lineage were detected in $\mathrm{H} 2$ viruses isolated in 178 Japan, and the H2 HA genes of Eurasian lineage was present in American birds. Our findings 
4179 highlight that the gene segments of Zb06 appear to have been derived from multiple virus

7

8 


\section{Acknowledgments}

We thank the Zambia Wildlife Authority for supporting the wild bird influenza A surveillance program in Zambia. We also thank K. Matsuno, H. Miyamoto, A. Ohnuma, and A. Yokoyama for excellent technical assistance. This work was supported by the Program of Founding Research Centers for Emerging and Reemerging Infectious Diseases from the Ministry of Education, Culture, Sports, Science and Technology (MEXT), Japan.

\section{References}

1. Banks J, Speidel ES, Moore E, Plowright L, Piccirillo A, Capua I, Cordioli P, Fioretti A, and Alexander DJ (2001) Changes in the haemagglutinin and the neuraminidase genes prior to the emergence of highly pathogenic H7N1 avian influenza viruses in Italy. Arch Virol 146: 963-973.

2. Bean WJ, Schell M, Katz J, Kawaoka Y, Neave C, Gorman O, Webster RG (1992) Evolution of the H3 influenza virus hemagglutinin from human and nonhuman hosts. J Virol 66: 1129-1138

3. Campitelli L, Di Martino A, Spagnolo D, Smith GJD, Di Trani L, Facchini M, De Marco MA, Foni E, Chiapponi C, Martin AM, Chen H, Guan Y, Delogu M, and Donatelli I (2008) Molecular analysis of avian H7 influenza viruses circulating in Eurasia in 19992005: detection of multiple reassortant virus genotypes. J Gen Virol 89: 48 - 59.

4. Campitelli L, Mogavero E, De Marco MA, Delogu M, Puzelli S, Frezza F, Facchini M, Chiapponi C, Foni E, Cordioli P, Webby R, Barigazzi G, Webster RG, and Donatelli I (2004) Interspecies transmission of an H7N3 influenza virus from wild birds to intensively reared domestic poultry in Italy. Virology 323: 24-36.

5. Chen H, Smith G. J. D, Zhang SY, Qin K, Wang J, Li KS, Webster RG, Peiris JSM, and Guan Y (2005) H5N1 virus outbreak in migratory waterfowl. Nature 436: 191-192

6. Crawford RJM, Cooper J, and Dyer BM (1995) Conservation of an increasing population of Great White Pelicans Pelecanus onocrotalus in South Africa's Western Cape. South African Journal of Marine Science 15: 33-42.

7. Crawford RJM, Cooper J, and Shelton PA (1981) The breeding population of White pelicans Pelecanus onocrotalus at Bird Rock Platform in Walvis Bay, 1949-1978. Fisheries Bulletin of South Africa 15: 67-70. 
12. Hoffmann E, Stech J, Guan Y, Webster RG, Perez DR (2001) Universal primer set for the full-length amplification of all influenza A viruses. Arch Virol 146: 2275-2289.

13. Horimoto T, Kawaoka Y (2001) Pandemic threat posed by avian influenza A viruses. Clin Microbiol Rev $14: 129-149$

14. Kilpatrick AM, Chmura AA, Gibbons DW, Fleischer RC, Marra PP, et al (2006) Predicting the global spread of H5N1 avian influenza. Proc Natl Acad Sci U S A 103: 19368-19373.

15. Li KS, Guan Y, Wang J, Smith GJD, Xu KM, Duan L, Rahardjo AP, Puthavathana P, Buranathai C, Nguyen TD, Estoepangestie ATS, Chaisingh A, Auewarakul P, Long HT, Hanh NTH, Webby RJ, Poon LLM, Chen H, Shortridge KF, Yuen KY, Webster RG, and Pieris JSM (2004) Genesis of highly pathogenic and potentially pandemic H5N1 influenza virus in eastern Asia. Nature 430: 209-213.

16. Liu J, Okazaki K, Bai G, Shi W, Mweene A, Kida H (2004) Interregional transmission of the internal protein genes of $\mathrm{H} 2$ influenza virus in migratory ducks from North America to Eurasia. Virus Genes 29, 81-86

17. Mackenzie JS, Edwards EC, et al (1984) Isolation of ortho- and paramyxoviruses from wild birds in Western Australia, and the characterization of novel influenza A viruses. Australian Journal of Experimental Biology \& Medical Science 62(Pt 1): 89-99. 
18. Makarova NV, Kaverin NV, Krauss S, Senne D, Webster RG (1999) Transmission of Eurasian avian H2 influenza virus to shorebirds in North America. J Gen Virol 80, 31673171

19. Munster VJ, Baas C, Lexmond P, Waldenstro“m J, Wallensten A, et al (2007) Spatial, temporal, and species variation in prevalence of influenza A viruses in wild migratory birds. PLoS Pathog 3(5): e61. doi:10.1371/journal.ppat.0030061

20. Olsen B, Munster VJ, Wallensten A, Waldenstrom J, Osterhaus AD, Fouchier RA (2006) Global patterns of influenza a virus in wild birds. Science 312: 384-388.

21. Song MS, Oh TK, Moon HJ, Yoo DW, Lee EH, Lee JS, Kim CJ, Yoo GJ, Kim H, Choi YK (2008) Ecology of H3 avian influenza viruses in Korea and assessment of their pathogenic potentials. J Gen Virol 89: 949-57.

22. Suss J, Schafer J, et al (1994) Influenza virus subtypes in aquatic birds of eastern Germany. Archives of Virology 135(1-2): 101-14.

23. Underhill LG, Tree AJ, Oschadleus HD, and Parker V (1999) Review of Ring Recoveries of Waterbirds in Southern Africa. Cape Town: Avian Demography Unit, University of Cape Town, South Africa.

24. Webster RG, Bean WJ, Gorman TO, Chambers TM, and Kawaoka Y (1992) Evolution and ecology of influenza viruses. Microbiol Rev 56: 152-179.

25. WHO (2009) Cumulative Number of Confirmed Human Cases of Avian Influenza $\mathrm{A} /(\mathrm{H} 5 \mathrm{~N} 1)$ reported to WHO. http://www.who.int/csr/disease/avian_influenza /country/cases_table_2009_06_02/en/index.html. Accessed 17 June 2009 
TABLE 1. Antigenic characterization of Zb06 by HI and NI assays

\begin{tabular}{|c|c|c|c|c|c|c|c|c|c|c|c|c|}
\hline \multirow[b]{2}{*}{ Virus } & \multicolumn{5}{|c|}{ HI titer of chicken antisera } & \multicolumn{7}{|c|}{ NI titer of chicken antisera } \\
\hline & Subtype & Zb06 & Aichi & Mem96 & PR8 & Virus & Subtype & Zb06 & Eng56 & MD77 & Czec56 & PR8 \\
\hline $\mathrm{Zb06}$ & H3N6 & $\underline{5,120}^{\mathrm{a}}$ & 320 & $<40$ & $<40$ & $\mathrm{Zb06}$ & H3N6 & $2,560^{a}$ & 2,560 & 640 & 320 & $<10$ \\
\hline Aichi & $\mathrm{H} 3 \mathrm{~N} 2$ & 5,120 & $\underline{10,240}$ & 160 & $<40$ & Eng56 & H11N6 & 1,280 & $\underline{2,560}$ & 320 & 320 & $<10$ \\
\hline Mem96 & $\mathrm{H} 3 \mathrm{~N} 2$ & 2,560 & $<40$ & $\underline{10,240}$ & $<40$ & MD77 & H13N6 & 5,120 & 2,560 & $\underline{1,280}$ & 640 & $<10$ \\
\hline DHK836 & $\mathrm{H} 3 \mathrm{~N} 1$ & 2,560 & 640 & $<40$ & $<40$ & Czec56 & H4N6 & 2,560 & 2,560 & 1,280 & $\underline{1,280}$ & $<10$ \\
\hline PR8 & $\mathrm{H} 1 \mathrm{~N} 1$ & $<40$ & $<40$ & $<40$ & $\underline{5,120}$ & PR8 & H1N1 & $<10$ & $<10$ & $<10$ & $<10$ & $\underline{1,280}$ \\
\hline
\end{tabular}

$269{ }^{\mathrm{a}}$ Homologous HI and NI titers are in boldface type and are underlined 
270 TABLE 2. Influenza viruses with highest nucleotide sequence similarity to Zb06 
4271 Fig. 1 Phylogenetic relationships of the HA (a), NA (b), NP (c), and PA (d) genes of Zb06.

272 Numbers next to the branches indicate neighbor-joining bootstrap values of $\geq 50 \%$. All positions

8

273 containing gaps and missing data were eliminated from the dataset (Complete deletion option). 


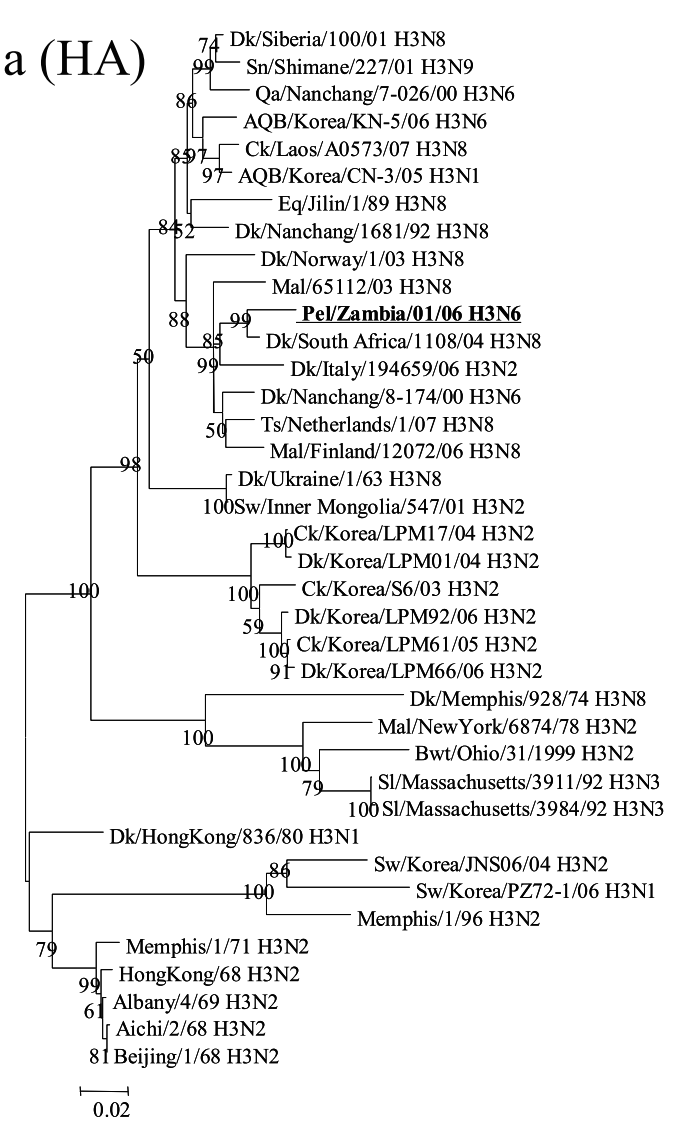

c (NP)

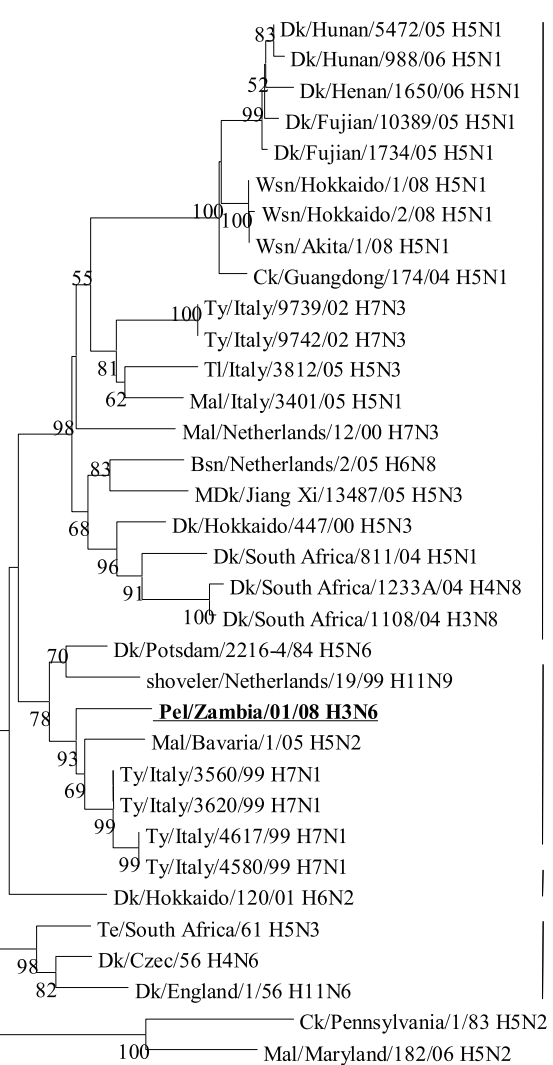

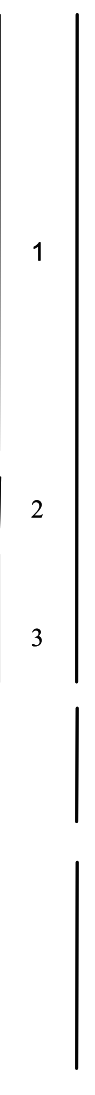

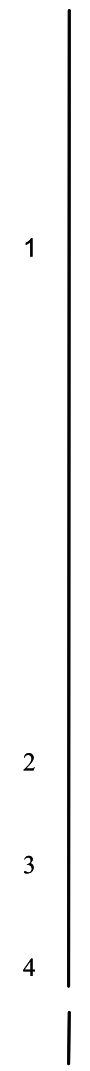

Eurasia

America

Human-swine

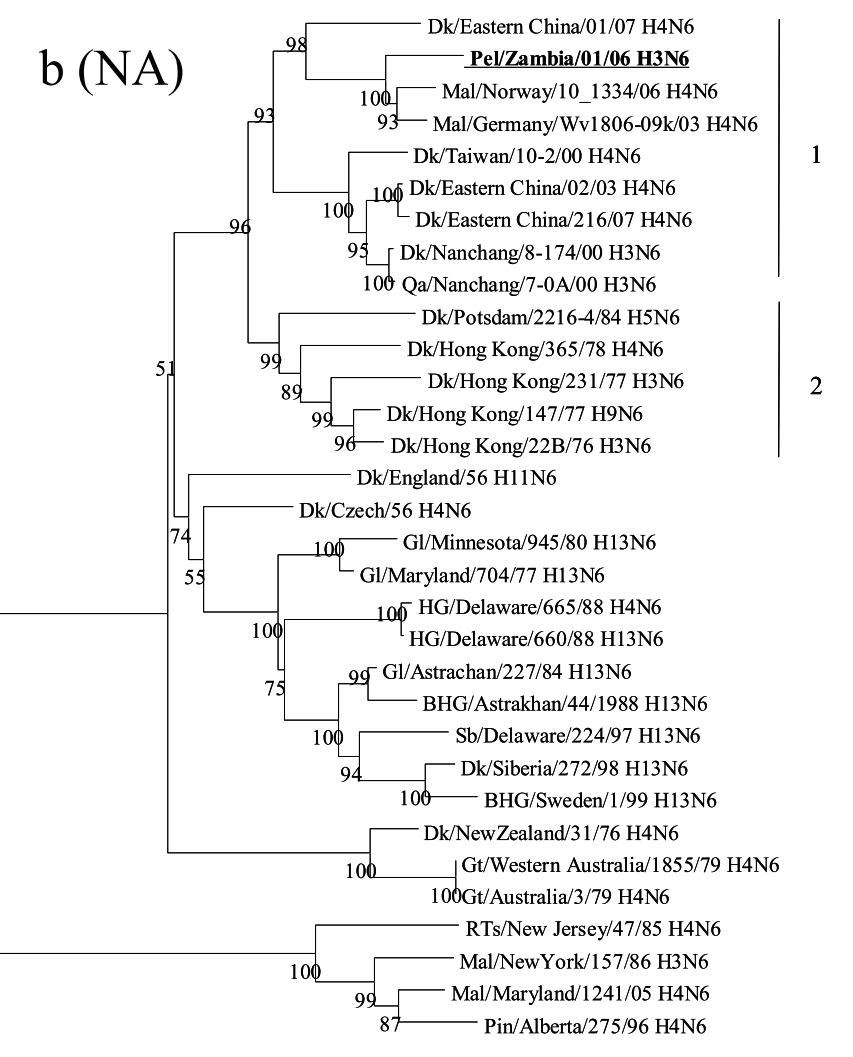

Eurasia

Eurasia/America

Oceania

America



America
Eurasia 

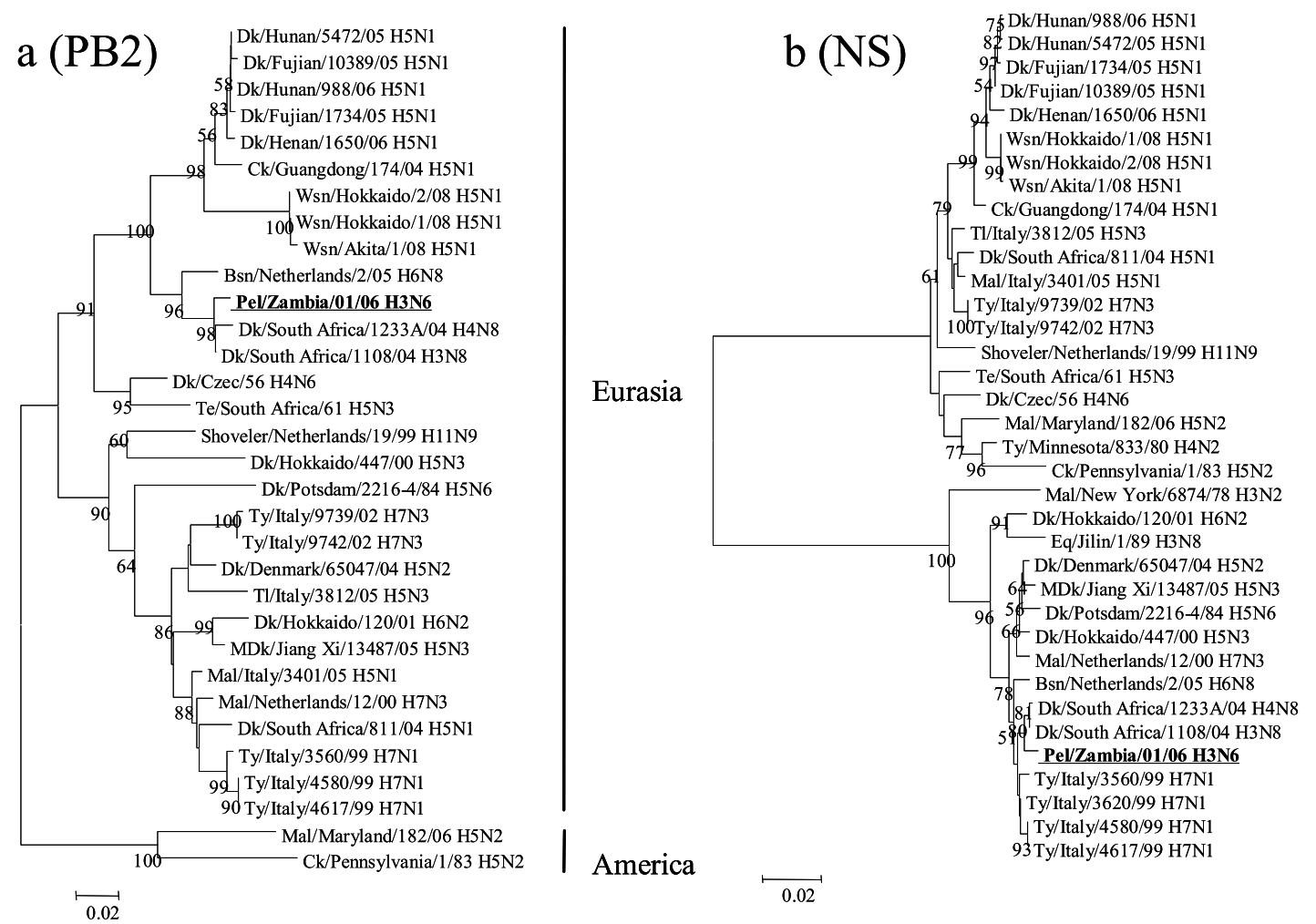

Eurasia

Allele A

0.02
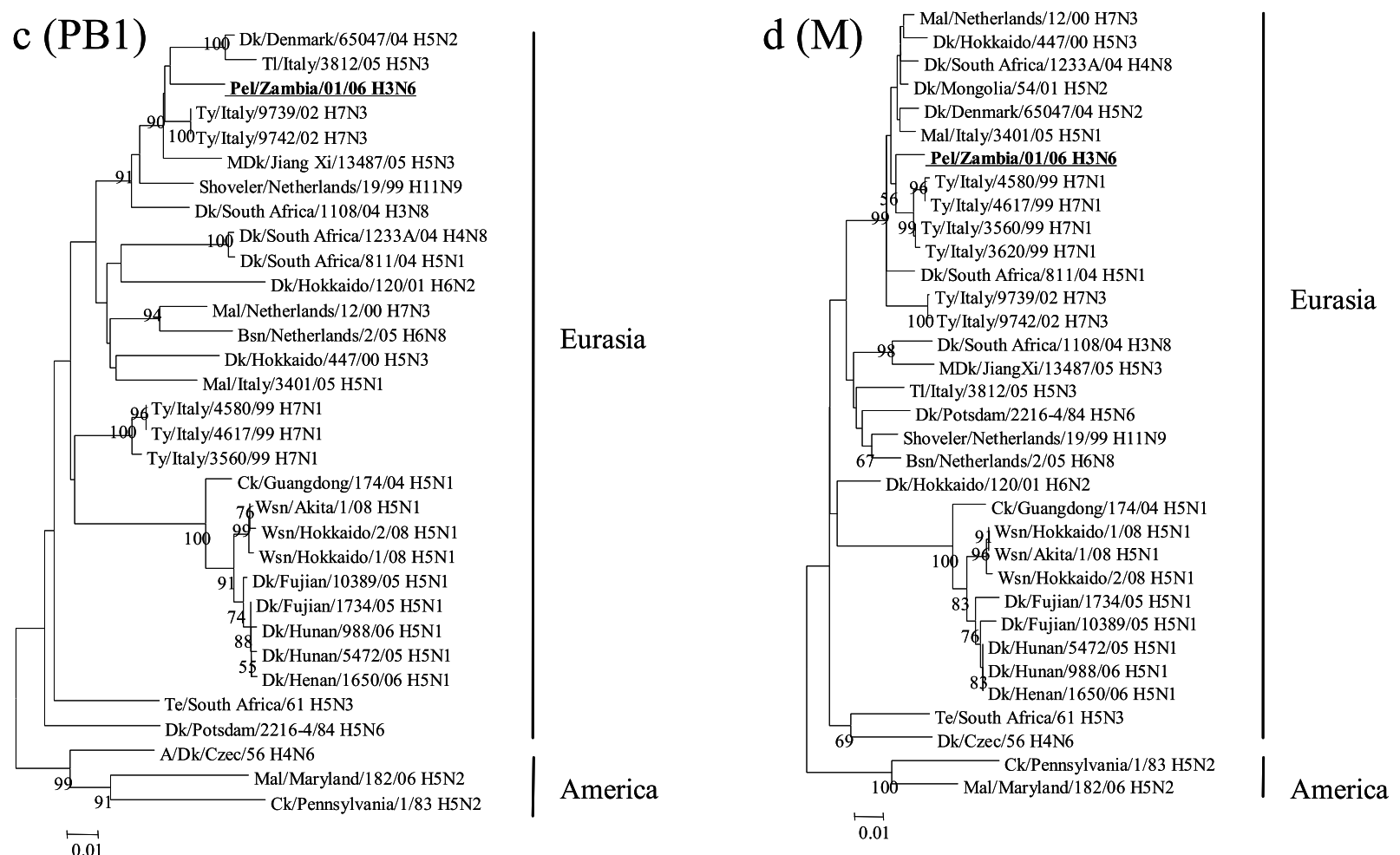

$\overleftrightarrow{0.01}$

Supplementary Fig. S1 Phylogenetic relationships of the PB2 (a), NS (b), PB1 (c), and M (d) genes of Zb06. Numbers next to the branches indicate neighbor-joining bootstrap values of $\geq 50 \%$. The virus strain sequenced in the present study is in bold and underlined. Analysis was based on the following nucleotides: PB2 $(1,468-2,193)$, NS (57-711), PB1 (1,429-2,178), and M (197-868). 